\title{
ANALYSIS OF THE FEASIBILITY OF REDUCING FUEL CONSUMPTION AND CARBON-DIOXIDE EMISSIONS AND OBTAINING CARBON CREDITS WITH THE USE OF SVERDLOVSKAYA-OBLAST FACTORIES AS AN EXAMPLE
}

V. P. Anufriev, ${ }^{1}$ V. G. Lisienko, ${ }^{1}$

UDC 669.1:620.9 A. P. Kuligin, ${ }^{1}$ A. V. Lapteva, ${ }^{1}$ Yu. N. Chesnokov, ${ }^{1}$ Yu. K. Malikov, ${ }^{1}$ and T. P. Ryzhova ${ }^{2}$

This article discusses aspects of improving the efficiency of heating and heat-treatment furnaces from the standpoint of the fuel savings that can be realized by the use of different methods to modernize such furnaces. Keywords: greenhouse gas, carbon dioxide, regenerative burner, thermal efficiency, monetary savings, automation.

The Sverdlovskaya Oblast has three pipe plants and several metallurgical, mining, and machine-building concerns. To obtain finished pipes or rolled products, semifinished products have to be heated to a certain temperature in different types of heating furnaces. The factories also have heat-treatment furnaces to heat finished products in order to give them the necessary properties. The number of heating and heat-treatment furnaces in all of the factories combined totals several hundred.

The main fuel used for these furnaces and units is natural gas. Complete combustion of the natural gas results in the formation of carbon dioxide (a greenhouse gas) [1]

$$
M_{G}=3.667 C^{P} M_{F} / 100,
$$

where $M_{G}$ is the mass of the carbon dioxide that is formed in the combustion of all of the fuel, tons/ton product; 3.667 is a coefficient which determines the mass of the carbon dioxide formed per unit mass of burned carbon; $C^{P}$ is the mass content of carbon in the fuel, \%; and $M_{F}$ is the mass of the burned natural gas, tons/ton product. The coefficient 3.667 was found from the equation that describes the complete oxidation of carbon. Thus, Eq. (1) includes the masses of the gases rather than their volumes.

The natural gas obtained from different gas fields differs in composition, which accounts for the differences in the carbon content and specific density of the gas. To simplify the approximate calculations being performed here, we will assume that the natural gas consists of just methane. By mass, such a gas will contain $75 \%$ carbon and have a specific density of $0.717 \mathrm{~g} /$ liter. Making these assumptions allows us to use several simplified relations.

\footnotetext{
${ }^{1}$ Yeltsin Ural Federal University (UrFU), Ekaterinburg, Russia; e-mail: ch_jur@mail.ru.

${ }^{2}$ Pervouralsk New Pipe Plant, Ekaterinburg, Russia.
}

Translated from Metallurg, No. 4, pp. 24-29, April, 2013. Original article submitted September 13, 2012. 


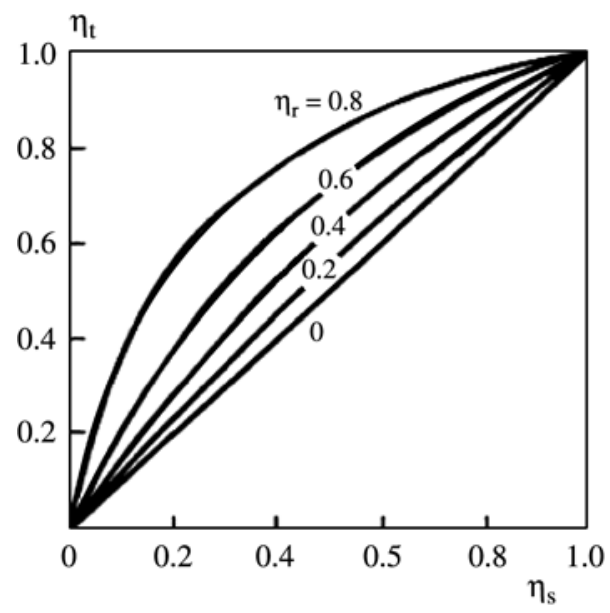

Fig. 1. Character of the dependence of $\eta_{t}$ on $\eta_{s}$ for different degrees of heat regeneration $\eta_{\mathrm{r}}$ (it was assumed that the quantities $\eta_{\mathrm{s}}$ and $\eta_{\mathrm{r}}$ were independent of one another and that $\eta_{\text {loss }}^{\prime}=\eta_{\text {loss }}^{\prime \prime}=0$ ).

The volume $V_{G}$ of $\mathrm{CO}_{2}$ that is formed $\left(\mathrm{m}^{3} /\right.$ ton product) by the combustion of methane is determined by the mass of the oxidized fuel:

$$
V_{G}=1855 \frac{75}{100} M_{F}
$$

where 1855 is the volume coefficient of the gas. This coefficient expresses the volume of gas formed per ton of mass of burned fuel with $C^{P}=100 \%$ and with allowance for the specific density of carbon dioxide $1.977 \mathrm{~kg} / \mathrm{m}^{3} ; 3.667 \cdot 1000 / 1.977=1855$; and $M_{F}$ is the mass of the burned methane, tons/ton product.

The specified volume of oxidized methane is used to determine the volume $V_{G}$ of $\mathrm{CO}_{2}$ that is formed ( $\mathrm{m}^{3} /$ ton product) by the combustion of methane, $1 \mathrm{~m}^{3}$ of which weighs 0.000717 tons. The value of $V_{G}$ is determined from Eq. (2) as

$$
V_{G}=0.997 V_{F},
$$

where 0.997 is the volume coefficient of the gas, which gives us the volume of carbon dioxide that is formed per unit volume of methane; $V_{F}$ is the volume of burned methane, $\mathrm{m}^{3} /$ ton product.

In addition to the hydrocarbon gases formed in the combustion of carbon dioxide, in its initial state natural gas also contains a certain percentage of carbon dioxide. We will ignore this quantity of carbon dioxide in order to simplify subsequent calculations. Otherwise, we would choose to use the actual composition of natural gas and calculate its carbon content and specific density.

It follows from the above formulas that in order to reduce emissions of $\mathrm{CO}_{2}$ by heating furnaces it is necessary to also reduce unit fuel consumption. There are several known methods of saving fuel. The present analysis will be concerned with one such method - increase the thermal efficiency of the heating operation, i.e., increase the value of the ratio of the useful heat obtained from the fuel to the heating capacity of the furnace. This is done in modern heating and heat-treatment furnaces by installing recuperators or regenerators which use the heat of the outgoing combustion gases to heat the air entering the burners.

In accordance with the formula obtained by Lisienko [2], thermal efficiency $\eta_{t}$ depends on the degree of heat regeneration $\eta_{\mathrm{r}}$ :

$$
\eta_{\mathrm{t}}=\eta_{\mathrm{s}} \frac{1-\eta_{\text {loss }}^{\prime \prime}\left(1-\eta_{\mathrm{s}}\right)}{1-\eta_{\mathrm{r}}\left(1-\eta_{\mathrm{s}}\right)}-\eta_{\text {loss }}^{\prime}
$$


TABLE 1. Energy Indices of Fuel Conservation and Carbon Credits Obtained with the Introduction of New Burners and a $45 \%$ Decrease in Natural-Gas Consumption

\begin{tabular}{|c|c|c|c|}
\hline No. & Index & Computational formula & Value \\
\hline 1 & $\begin{array}{l}\text { Unit consumption of fuel (natural gas) in heating furnaces without } \\
\text { the use of recuperative burners, } \mathrm{m}^{3} / \text { ton }\end{array}$ & - & 50 \\
\hline 2 & $\begin{array}{l}\text { Decrease in unit fuel consumption with the use of recuperative } \\
\text { burners, } \%\end{array}$ & - & 40 \\
\hline 3 & $\begin{array}{l}\text { Decrease in unit fuel consumption with the use of recuperative } \\
\text { burners, } \mathrm{m}^{3} / \text { ton }\end{array}$ & No. $3=$ No. $1 \times$ No. 2 & 20 \\
\hline 4 & Volume of production at the PNTZ, $10^{3}$ tons/month & - & 56.6 \\
\hline 5 & Volume of production at the PNTZ, $10^{3}$ tons/yr & No. $5=$ No. $4 \times 12$ & 679.2 \\
\hline 6 & Fuel savings at the PNTZ from introduction of the measure, $\mathrm{m}^{3} / \mathrm{yr}$ & - & 13584 \\
\hline 7 & $\begin{array}{l}\text { Emission coefficient for natural gas (with } Q_{\mathrm{n}}=8000 \mathrm{kcal} / \mathrm{m}^{3} \text { ), } \\
\text { tons } \mathrm{CO}_{2} / 10^{3} \mathrm{~m}^{3}\end{array}$ & - & 1.879 \\
\hline 8 & Reduction in $\mathrm{NG}$ emissions, tons $\mathrm{CO}_{2} / \mathrm{yr}$ & - & 25525 \\
\hline \multicolumn{4}{|c|}{ Economic indices of the project without allowance for carbon credits } \\
\hline 9 & Cost of one burner, $10^{3}$ rubles & & 500 \\
\hline 10 & Number of burners & & 1500 \\
\hline 11 & Expenditures on burners, $10^{3}$ rubles & & 750,000 \\
\hline 12 & Total expenditures on the project, $10^{3}$ rubles & No. $12=$ No. $11 \times 1.5$ & $1,125,000$ \\
\hline 13 & Price of natural gas (Pervouralsk region), $10^{3}$ rubles $/ 10^{3} \mathrm{~m}^{3}$ & - & 3.80 \\
\hline 14 & Monetary savings due to the fuel component, $10^{3}$ rubles/yr & No. $14=$ No. $6 \times$ No. 13 & 51614 \\
\hline 15 & Undiscounted investment recovery period, yr & No. 15 = No.12/No.14 & 21.797 \\
\hline \multicolumn{4}{|c|}{ Economic indices of the project with allowance for carbon credits } \\
\hline 16 & Total expenditures on the project, $10^{3}$ rubles & No. $12=$ No. $11 \times 1.5$ & $1,125,000$ \\
\hline 17 & Monetary savings due to the fuel savings, $10^{3}$ rubles/yr & No.14 = No. $6 \times$ No.13 & 51619 \\
\hline 18 & $\mathrm{ECB}$ value on the European market, euros/ton $\mathrm{CO}_{2}$ & - & 7.000 \\
\hline 19 & ECB value on the European market, rubles/ton $\mathrm{CO}_{2}$ & - & 280 \\
\hline 20 & $\begin{array}{l}\text { Revenue from the sale of carbon credits in the joint venture, } \\
10^{3} \text { rubles } / y r\end{array}$ & No. $20=$ No. $19 \times$ No. 8 & 7147 \\
\hline 21 & Total annual revenue from the project, $10^{3}$ rubles $/ y r$ & No.21 = No. $20+$ No. 17 & 58761 \\
\hline 22 & Undiscounted investment recovery period, yr & No. $22=$ No. $17 /$ No. 21 & 19.145 \\
\hline
\end{tabular}

where $\eta_{\mathrm{s}}$ is the efficiency of the working space of the furnace (heat-exchange efficiency); $\eta_{\text {loss }}^{\prime}$ is a coefficient that expresses the amount of heat lost as a result of conduction through the guides and the accumulation of heat in the furnace lining; and $\eta_{\text {loss }}^{\prime \prime}$ is a coefficient expressing the amount of heat lost as a result of chemical and mechanical underfiring of the fuel. Figure 1 shows the dependence of thermal efficiency on heat-exchange efficiency according to Eq. (4) (without allowance heat regeneration). An analysis shows that with $\eta_{\mathrm{s}}=0.4$ (for example), thermal efficiency can be nearly doubled by increasing the degree of heat regeneration from $\eta_{\mathrm{r}}=0$ to $\eta_{\mathrm{r}}=0.8$.

Old heating furnaces are sometimes operated without recuperators (with $\eta_{\mathrm{S}}=0$ ) and with very high values of unit fuel consumption. Most furnaces have recuperators made of ceramic or metal tubes. The infiltration of air into the flue chan- 
nel markedly reduces the temperature of the flue gases before they reach a metal recuperator. As a result, the temperature of the air leaving the recuperator is no higher than $300-400^{\circ} \mathrm{C}$ and is often appreciably less. Ceramic recuperators are non-hermetic and are characterized by large air leaks, which disrupts the process of regulating combustion of the fuel [3]. The fuel savings realized with the above-described recuperators range up to 20\% [2]. Regenerative burners have now been developed, the checkers of these burners being capable of heating air to $1000^{\circ} \mathrm{C}$ or more. Fuel savings in such burners reach 55-65\% or higher [2]. Recuperative burners are also in use [2], these burners heating air to $820^{\circ} \mathrm{C}$. The fuel savings realized in this case does not exceed $40 \%$.

Lower fuel consumption leads to a reduction in greenhouse-gas $\left(\mathrm{CO}_{2}\right)$ emissions. For example, $50 \mathrm{~m}^{3}$ of natural gas is burned for each ton of semifinished product in furnaces used to heat semifinished products prior to rolling. For natural gas with a methane content of $99 \%$ (carbon content $75 \%$ and specific density $0.717 \mathrm{~kg} / \mathrm{m}^{3}$ ), we can take $M_{S F}=50 \cdot 0.717=35.85 \mathrm{~kg} / \mathrm{ton}$ semifinished product as the mass of the natural gas that is consumed. This amount of gas will contain $26.8875 \mathrm{~kg}$ of carbon. Then the carbon-based unit emissions coefficient of the heating furnace will be equal to $26.8875 \cdot 3.667=98.5965 \mathrm{~kg} / \mathrm{ton}$ semifinished product, which can also be expressed as $49.87 \mathrm{~m}^{3} /$ ton semifinished product or $1971.93 \mathrm{~kg} \mathrm{CO}_{2} / 1000 \mathrm{~m}^{3}$.

Let us examine and generalize the experience gained from several typical instances of the reconstruction of heatengineering facilities under current conditions. We will analyze the results obtained from the introduction - mainly in the Sverdlovskaya Oblast - of modern burners equipped with individual recuperators or even regenerators.

We should mention that it is best to replace the existing burner units with burners of new designs when heating and heat-treatment furnaces and other heat-engineering facilities are being rebuilt. The new burners are usually equipped with an automatic ignition system, ultraviolet flame detector, and individual regulators for gas consumption and the gas-air ratio. High-speed burners that operate in a pulsed regime are also in use.

We will analyze the possibilities presented by the use of recuperative burners by examining heating and heat-treatment furnaces at one pipe plant as an example. Fuel (natural gas) consumption on the furnaces was reduced from 80 to $44 \mathrm{~m}^{3} /$ ton, i.e., by $45 \%$. The volume of production is 679,200 tons of product a year. The results of the calculations are shown in Table 1 .

It was found that in regard to the monetary savings from the reduction in natural-gas use, the relative value of the carbon credit is $7147 / 51614 \cdot 100 \%=14 \%$.

In the general case, the ratio of the savings from reduced natural-gas use to the size of the carbon credit $\gamma_{\text {in }}$ can be calculated from the formula

$$
\gamma_{\text {in }}=\mathrm{C}_{\mathrm{CO}_{2}} \beta_{\mathrm{em}} / \mathrm{C}_{\mathrm{nr} . \mathrm{g}}
$$

where $\mathrm{C}_{\mathrm{CO}_{2}}$ represents the unit carbon credit, rubles/ton $\mathrm{CO}_{2} ; \mathrm{C}_{\mathrm{nr.g}}$ is the price of natural gas, rubles $/ 1000 \mathrm{~m}^{3}$; and $\beta_{\mathrm{em}}=1.879$ tons $\mathrm{CO}_{2} / 10^{3} \mathrm{~m}^{3}$ is the $\mathrm{CO}_{2}$ emission coefficient for natural gas.

Thus, with natural gas at a price of 3800 rubles $/ 10^{3} \mathrm{~m}^{3}$ in Russia, the unit carbon credit is $\$ 9$ (270 rubles)/ton $\mathrm{CO}_{2}$. This means that for $\beta_{\mathrm{em}}=1.879$ tons $\mathrm{CO}_{2} / 10^{3} \mathrm{~m}^{3}$ the relative carbon credit $\gamma_{\text {in }}$ is equal to

$$
\gamma_{\text {in }}=270 \cdot 1.879 / 3800=0.1335 \text { rubles } \mathrm{CO}_{2} / \text { rubles nr.g, }
$$

i.e., the relative carbon credit is also close to $14 \%$.

It can be seen from Table 1 that since 200,000 rubles is the cost of one burner unit and 5000 is the number of such units needed by the factories in the Sverdlovskaya Oblast, the total monetary savings which is realized for the above-indicated fuel savings means that the undiscounted investment recovery period is very long ( 19 years).

Finally, it should be noted that up till now there have been subsidies for natural gas in Russia. For the calculations being performed here, we took 3800 rubles $(\$ 120) / 1000 \mathrm{~m}^{3}$ as the value of the subsidies. If we were to use the significantly higher values which exist in the international market (up to $\$ 350 / 1000 \mathrm{~m}^{3}$ ), the monetary savings that would be obtained in Russia by reducing natural-gas use could be $2-3$ times larger and there would be a corresponding reduction in the investment recovery period and a corresponding increase in the funds available for possible additional investments (in burners, heatexchangers, automation equipment, refractories, and new technologies and buildings). Specifically, the investment recovery period would be shortened to a more acceptable level on the order of 4-6 years. 
Even with a reduction in natural-gas use by $40-50 \%$ in the new burners, the above calculations show that by their very nature the "standard" methods of burner operation result in a relatively small total monetary savings under the conditions that currently exist in Russia.

However, a look at the best practices being followed in the modernization of a number of Russian factories shows there are much better opportunities for saving fuel and obtaining the corresponding carbon credits. In these cases, significant monetary savings are being obtained by the realization of additional improvements (which generally include upgrading of the existing furnaces). Among these improvements is the use of new designs of burners, an increase in productivity, a reduction in product rejection rate, and modernization of furnace equipment (including upgrading of the burners). The connection between equipment upgrades and subsequent monetary savings is illustrated by the results being obtained by the Pervouralsk New Pipe Plant (PNTZ) from the reconstruction of several of its heating and heat-treatment furnaces.

Experience shows that if natural-gas consumption is reduced significantly (by a factor of two or more) by modernizing existing heating and heat-treatment furnaces with the installation of new automated burners, then even at current Russian natural-gas prices the capital investment made in such modernization can be recouped in 2-3 years.

Considerable experience in this area has been gained in particular by the Research Center for Energy Conservation and Automation at Ural Federal University in a collaborative effort between the center and the Gas Engineering ScientificIndustrial Association. As noted above, it has been found that in certain cases the modernization of heating and heat-treatment furnaces involves not only replacement of the existing burners but also the implementation of several other measures that are cost-effective from the technological and heat-engineering perspective. The adoption of such measures is resulting in much greater (by several-fold) fuel conservation.

For example, by modernizing the heating chamber of a roller-hearth furnace used to heat-treat tubular semifinished products and taking other steps (changing the heat-treatment regimes and automating the heating operation to improve its accuracy) while also installing 12 high-speed pulse-type burners, one Russian plant was able to reduce its consumption of natural gas from 146 to $81 \mathrm{~kg}$ comparison fuel/ton, i.e., by a factor of 1.8 [4]. Here, the decrease realized in the consumption of natural gas $\left(\delta_{\text {nr.g }}\right)-$ which has a heat of combustion $Q_{\mathrm{n}}^{\mathrm{c}}=8500 \mathrm{kcal} / \mathrm{m}^{3}-\mathrm{is} \delta_{\mathrm{nr.g}}=(65 \cdot 7000) / 8500=53.5 \mathrm{~m}^{3} / \mathrm{ton}$. This ensures a reduction in $\mathrm{CO}_{2}$ emissions by $\delta_{\mathrm{CO}_{2}}=1.879 .53 .5=100.52$ tons/ton and results in a fairly substantial carbon credit of $\Delta_{\text {in }}=270 \cdot 100.52=27142.2$ rubles/ton.

In another example, the modernization of a heat-treatment furnace at one Russian factory entailed the replacement of 35 burner blocks - closed-end radial tubes with a ceramic recuperator (the air is heated to $600^{\circ} \mathrm{C}$ ). At a cost of 400,000 rubles per block, the capital investment was $35 \cdot 400,000=14,000,000$ rubles. The upgrade resulted in an average reduction in fuel consumption by a factor of 2.5-3 and the corresponding monetary savings was $S_{f}=6$ million rubles. Thus, the investment in the burners was recovered in 2.33 years. The total cost of the furnace upgrade was 125 million rubles, but the total monetary savings (from the decrease in natural-gas use, attainment of a heating accuracy of $2-3^{\circ} \mathrm{C}$, elimination of product rejection, and the improvement in the quality of the product along with the associated increase in its sale price) was 61.6 million rubles. Thus, the total capital cost of the furnace modernization was recouped in about 2.03 years. Taking $\gamma_{\text {in }}=0.1335$ rubles/ruble, we find that the modernization project also results in a carbon credit $S_{c b}=\gamma_{\text {in }} S_{f}=0.1335 \cdot 6=0.801$ million rubles, i.e., the annual gain in revenue from the reduction in fuel use is additionally increased by $13.35 \%$.

The fact that such projects are being carried out with the use of new heating systems - direct-gas heating (DGH) systems for heating ventilation air [5] (particularly in deep-lying shafts) - is resulting in a significant savings of natural gas compared to systems in which ventilation air is heated in calorifiers with steam heat. The use of DGH in a shaft in which the air had previously been heated in a calorifier by steam from a boiler made it possible to reduce gas consumption threefold and realize a gas savings of roughly $2000 \mathrm{~m}^{3} / \mathrm{h}$. Over 1500 hours of operation of a DGH system during the heating season, the savings in natural gas is $2000 \cdot 1500=3,000,000 \mathrm{~m}^{3} / \mathrm{yr}$. This ensures a decrease in $\delta_{\mathrm{CO}_{2}}=1.879 \cdot 3=5.637$ million tons $/ \mathrm{yr}$. With natural gas costing 3.8 rubles $/ \mathrm{m}^{3}$, the monetary savings is $3 \cdot 3.8=11.4$ million rubles/yr. The capital investment was 35 million rubles and the recovery period was 3.07 years. In this case, the carbon credit $\Delta_{\text {in }}$ will be:

$$
\Delta_{\text {in }}=\mathrm{S}_{\mathrm{f}} \gamma_{\text {in }}=11.4 \cdot 0.1335=1.522 \text { million rubles } / \mathrm{yr} .
$$




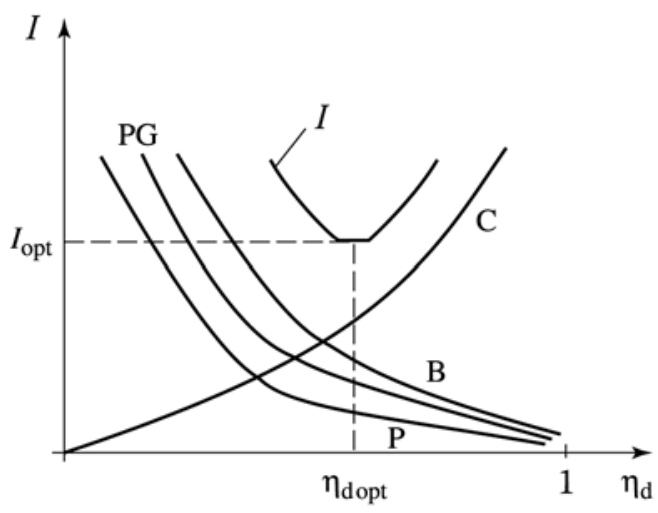

Fig. 2. Dependence of the optimization criterion $I$ on direct heat-transfer efficiency $\eta_{d}$ with a decrease in fuel consumption: $\mathrm{B}$ - fuel costs; $\mathrm{P}$ - penalty for harmful emissions; PG - penalty for greenhouse-gas emissions; $\mathrm{C}$ - capital costs; $I$ - the sum of the fuel costs: the penalty for harmful emissions, the penalty for greenhouse-gas emissions, and the capital costs.

Let us present some suitable examples based on data for other organizations. For instance, when 44 recuperative ReKumat M250 burners made by WS GmbH were installed on heat-treatment furnaces at the Trubodetal (in Chelyabinsk), gas consumption was reduced by a factor of 3.1 compared to the level seen previously with the use of GNP burners. Since the price of gas is 3.25 rubles $/ \mathrm{m}^{3}$ and each new burner costs 302,000 rubles, the period needed to recoup the latter expenditure just as a result of the savings in gas use is no more than $2.17 \mathrm{yrs}[6]$. The annual monetary savings $\mathrm{S}_{\mathrm{f}}$ was determined to be 0.725 million rubles. Accordingly, the carbon credit $S_{c b}=\gamma_{i n} S_{f}=0.1335 \cdot 0.725=0.097$ million rubles.

The experience of the NPK Uraltermokompleks in using recuperative burners made by the companies Kromschröder and WS was described in [7]. Data reported on the reduction that occurred in fuel consumption with the installation of recuperative Ecomax burners made by Kromschröder on a roller-hearth heat-treatment furnace showed that fuel use declined by a factor of 1.5-1.6. This decrease brings a corresponding reduction in $\mathrm{CO}_{2}$ emissions.

Among the advances being made on burners in Russia, we should mention the automated high-speed burner developed by GSS TESKA. This model of burner is $2-2.5$ times less expensive than the corresponding foreign units [8]. It results in a fuel savings of up to $30 \%$. As shown by previous calculations, however, such a decrease does not lead to a significant monetary savings at the natural-gas prices currently in effect in Russia. Despite this, the previous examples also illustrate that the introduction of the Russian-made burner at a wide range of metallurgical and machine-building plants (mainly in the Sverdlovskaya and Chelyabinsk Oblasts) could significantly increase productivity, improve the quality of the heating operation, and substantially reduce harmful emissions - which generally results in an appreciable monetary savings.

Mention should also be made of the unique experience gained with the use of recuperative burners designed by VNIIMT [G. M. Druzhinin private message] on one heating furnace [2, 9]. The regenerators are in the form of compact bulkmaterial packings, each packing having a volume of $0.232 \mathrm{~m}^{3}$. Air is heated to $1050^{\circ} \mathrm{C}$. Natural-gas consumption was reduced from 650 to $320 \mathrm{~m}^{3} / \mathrm{h}$ through use of the regenerators. If we convert a $330 \mathrm{~m}^{3} / \mathrm{h}$ reduction in natural-gas use into the corresponding monetary savings for a natural-gas price of $3.25 \mathrm{rubles} / \mathrm{m}^{3}$, we find that the annual cost savings turns out to be 7.72 million rubles. Given that the cost of each burner is 200,000 rubles, the period of time needed to recoup the capital investment is a record 0.2/3.25 $=0.062$ yrs even without consideration of the other investments made to modernize the furnace. The above-indicated fuel savings ensures a decrease in $\mathrm{CO}_{2}$ emissions $\delta_{\mathrm{CO}_{2}}=1.879 \cdot 7.72=14.51$ million tons/yr, which earns a carbon credit $\Delta_{\text {in }}=0.1335 \cdot 14.51=1.936$ million rubles/yr.

Internationally, continuing efforts are being made to further improve the technologies by which natural gas is used in heat-engineering equipment. Here, a major focus of these efforts is the need to reduce not only harmful emissions but also their content of greenhouse gases. One example is the work being done at the Institute of Gas Technologies in the U.S. on the development of thermochemical recuperators. These units can be used together with other units whose operation is based 
on the Maisotsenko cycle. Such recuperators separate natural gas into two fuel gases - hydrogen and carbon dioxide - and while simultaneously recovering the heat of the combustion products and thus increasing thermal efficiency [8].

As is known, when fuel consumption is reduced, there is a corresponding tendency for the volume of harmful emissions to also decrease [2]. The above-examined relations which link fuel savings to capital expenditures with allowance for carbon credits can be used to further investigate the use of generalized optimization criterion $I$ in modernization projects in which the lowest value of direct heat-exchange efficiency $\left(\eta_{d}\right)$ that is optimal at the minimum value $I=I_{\text {opt }}$ is determined [3]. In this case, we take the well-known criterion $I$ - which is the sum of the fuel costs B and the penalty for harmful emissions $\mathrm{P}$ minus the capital costs $\mathrm{C}$ - and add to it the decrease in the penalty for emissions of greenhouse gases from natural gas (the carbon credits increase in this case). It is apparent that the optimum value of $\eta_{d}$ is shifted in the direction of larger values of $\eta_{d}$ with allowance for $\gamma_{\text {in }}$ (see Eq. (4)). In the present case, $\gamma_{\text {in }}=13-14 \%$ of the reduction in natural-gas consumption (Fig. 2). The relationship between $\eta_{s}$ and $\eta_{d}$ is shown by the formulas

$$
\eta_{\mathrm{s}}=\theta \eta_{\mathrm{d}} ; \quad \eta_{\mathrm{d}}=\eta_{\mathrm{s}} / \theta
$$

where $\theta$ is a relative parameter characterizing the initial heating of the material:

$$
\theta=\left(T_{2}^{\prime}-T_{1}^{\prime}\right) /\left(T_{2}^{\prime}-T_{0}\right)
$$

where $T_{2}^{\prime}$ and $T_{1}^{\prime}$ are the initial temperatures of the combustion products and the material being heated, respectively; $T_{0}$ is the ambient temperature.

Conclusion. The above analysis of the methods currently being used to upgrade heating and heat-treatment furnaces at factories - including the use of recuperative and regenerative burners - confirms that these methods are very effective and result in significant savings of fuel while also reducing harmful emissions and earning carbon credits for the factories.

\section{REFERENCES}

1. Yu. N. Chesnokov, V. G. Lisienko, and A. V. Lapteva, "Graph model for carbon dioxide emissions from metallurgical plants," Metallurg, No. 12, 23-26 (2012).

2. V. G. Lisienko (ed.), Ya. M. Shchelokov, and M. G. Ladygichev, Fuel: Efficient Combustion, Control, and Industrial Use: Handbook [in Russian], Teplotekhnik, Moscow (2004), Vol. 1 of 3.

3. V. I. Gubinskii, "Heating furnaces in metallurgy - today and tomorrow," Teor. Prakt. Metallurgii, No. 6, 56-60 (2004).

4. V. G. Lisienko, G. K. Malikov, Yu. K. Malikov, et al., "Current approaches to devising methods of conducting pre-project model studies in the development of industrial furnaces and heating equipment in the Twenty-First Century," in: Proc. 3rd Int. Congr. Furnace and Kiln Design: Thermal Calculations, Designs, Automation, and Ecology, V. G. Lisienko (ed.), Ekaterinburg, Inzhenernaya Mysl (2008), pp. 6-23.

5. V. G. Lisienko (ed.), Ya. M. Shchelokov, and M. G. Ladygichev, Selected Readings on Energy Conservation [in Russian], Teplotekhnik, Moscow (2002), Book 2 of 2.

6. S. V. D'yakov, A. V. D'yakov, and A. E. Makii, "Experience with the use of WS burners in heating and heat-treatment furnaces," Oborudovanie, No. 1, 14-16 (2009).

7. M. D. Kazyaev, A. F. Spiglazov, B. N. Arseev, et al., "The use of modern fuel-saving devices in heating furnaces," in: Proc. 3rd Int. Congr. Furnace and Kiln Design: Thermal Calculations, Designs, Automation, and Ecology, V. G. Lisienko (ed.), Ekaterinburg, Inzhenernaya Mysl (2008), pp. 152-159.

8. A. V. Frolov, "TESKA technology for rapid heating. Automated multi-purpose GSS TESKA burners," in: Proc. 2nd Int. Congr. Furnace and Kiln Design: Thermal Calculations, Designs, Automation, and Ecology, V. G. Lisienko (ed.), Ekaterinburg, Inzhenernaya Mysl (2006), pp. 298-300. 
9. G. M. Druzhinin, I. M. Distergeft, and V. I. Shcherbinin, "The experience of VNIIMT in developing regenerative heating systems for metallurgical equipment," Stal, No. 7, 84-89 (2000).

10. V. Maisotsenko, I. Gillan, and A. Kozlov, "The Maisotsenko cycle for power generation, waste energy recovery, and water reclamation," Clean Energy Supercluster Forum, Engines and Energy Conversion Laboratory, Colorado State University, IDALEX-GTI, Oct. 25, 2010, pp. 1-41. 